\title{
PSIHIČKI SIMPTOMI I KVALITETA ŽIVOTA STUDENATA IZ OBITELJI S ISKUSTVOM RATA
}

\author{
Irena Babić, Dragan Babić, Marko Martinac, Ivan Vasilj, Marina Vasilj
}

Fakultet zdravstvenih studija, Sveučilište u Mostaru, Bijeli Brijeg BB Mostar 88300, Bosna i Hercegovina

Rad je primljen 16.04.2016. R Rad je recenziran 11.05.2016. Rad je prihvaćen 29.05.2016.

\section{SAŽETAK}

UVOD: Dosadašnja istraživanja konzistentno pokazuju povezanost ratnog PTSP-a veterana i psihopatoloških simptoma u članova njihovih obitelji. Negativni utjecaj psihološke traume na osobe bliske pojedincu oboljelom od PTSP-a konceptualiziran je pojmom sekundarne traumatizacije. Cilj ovog rada je ispitati psihičke simptome i kvalitetu života studenata iz obitelji s iskustvom rata.

ISPITANICI I METODE: U istraživanju su sudjelovali studenti sa Sveučilišta u Mostaru od prve od pete godine ( $\mathrm{n}=160$ ). Istraživanje je provedeno primjenom presječne studije, slučajnim odabirom među studentskom populacijom oba spola. Za istraživanje su korišteni Sociodemografski upitnik, Upitnik kvalitete života Svjetske zdravstvene organizacije WHOQOLBREF i Upitnik za samoprocjenu SCL- 90.

REZULTATI: Svi psihički simptomi statistički su značajnije izraženi kod studenata iz obitelji s iskustvom rata u odnosu na studente koji nisu član obitelji s iskustvom rata, osim opsesivno kompulzivnih simptoma. Psihotična obiljě̌ja statistički značajnije su izražena kod studenata iz obitelji s iskustvom rata u odnosu na studente koji nisu članovi obitelji s iskustvom rata kao i nespecifični simptomi. Simptomi somatizacije, anksioznosti te paranoje su statistički značajno izraženiji kod studenata čija je majka bila sudionik rata u odnosu na studente iz obitelji gdje su oba roditelja bili sudionici rata. Simptomi paranoje i nespecifični simptomi statistički značajno su izraženiji kod studenata čiji je član obitelji nastradao za vrijeme rata u odnosu na studente čiji član obitelji nije nastradao za vrijeme rata. Ne postoji statistički značajnija razlika niti u jednom području kvalitete života između studenata iz obitelji s iskustvom rata i studenta koji nisu član obitelji s iskustvom rata ZAKLJUČAK: Studenti iz obitelji s iskustvom rata imaju statistički značajno veću pojavnost psihičkih simptoma. Među ispitivanim skupinama ne postoji statistički značajna razlika u odnosu na kvalitetu života.

Ključne riječi: psihički simptomi, kvaliteta života, studenti, rat.

Osoba za razmjenu informacija:

Babić Irena, magistar sestrinstva

e-mail: babicirena28@gmail.com

\section{UVOD}

Prema podacima Svjetske Zdravstvene organizacije (SZO) rat ostavlja veliki utjecaj na mentalno zdravlje i psihosocijalno funkcioniranje stanovništva ratom pogođene zemlje. Procjenjuje su da se stopa mentalnih poremećaja udvostručuje nakon rata (1).

Najpoznatiji poremećaj koji se razvija u oko 15 $\%$ do $20 \%$ traumatiziranih osoba jest posttraumatski stresni poremećaj (PTSP). Posljedice traumatizacije očituju se i u drugim aspektima mentalnog zdravlja, u prvom redu povećanju depresivnosti, anksioznosti i ovisnosti (2). Istraživanja konzistentno pokazuju povezanost ratnog PTSP-a veterana i psihopatoloških simptoma u članova njihovih obitelji (3). Traumatski dogadaji pokreću čitav kompleks reakcija koje, pored formiranja kliničke slike PTSP uvode članove obitelji u niz sekundarnih traumatizacija koje ozbiljno remete funkcioniranje oboljelih i njihovih najbližih (4). 
Negativni utjecaj psihološke traume na osobe bliske pojedincu oboljelom od PTSP-a konceptualiziran je pojmom sekundarne traumatizacije. U užem smislu sekundarna traumatizacija odnosi se na prijenos noćnih mora, intruzivnih misli, bljeskova prisjećanja i ostalih simptoma koje tipično doživljavaju traumatizirani pojedinci, na osobe u njihovoj blizini. U širem smislu, odnosi se na bilo koji prijenos distresa s nekoga tko je doživio traumu na one u njegovoj blizini i uključuje širok spektar manifestacija distresa (5).

Utjecaj ratnog PTSP-a veterana na njihovu djecu je vrlo kompleksan. Psihopatološki simptomi u djece veterana oboljelih od PTSP-a nastaju kao rezultat interakcije različitih bioloških, psiholoških i okolinskih čimbenika (6). Novija istraživanja interakcije genetskih (5-HTTLPR varijanti gena za serotoninski transporter) i okolinskih čimbenika (traumatska iskustva, zlostavljanje u djetinjstvu, stresni događaji), kao i epigenetskih utjecaja traumatskog iskustva i neadekvatnih odgojnih postupaka roditelja koji nastaju kao rezultat traume na ekspresiju gena koji reguliraju odgovor organizma na stres (glukokortikoidni receptor i FK506 binding protein 5) te time povećanu reaktivnost na stres i razvoj psihičkih poremećaja, potvrđuju i omogućuju bolje razumijevanje trangeneracijskog prijenosa traume (7-10). Sistem zrcalnih neurona u ventralnom premotoričkom korteksu, koji je uključen u opservaciju ponašanja drugih i izvršavanje aktivnosti, zbog svoje uloge u imitaciji ponašanja, također može imati značajnu ulogu u razvoju psihopatologije $u$ djece veterana s PTSP-om (11).

Rosenheck i Fontana su istaknuli da se iz psihosocijalne perspektive traumatska iskustva s očeva na djecu mogu prenositi na tri načina (12). Prvo, ponašanje očeva s ratnim PTSP-om može biti uzrok nastanka psihopatoloških simptoma u djece. Djeca mogu biti direktno traumatizirana nasilnim i agresivnim ponašanjem očeva oboljelih od PTSP-a (13). Drugo, prijenos traumatskog iskustva s očeva na dijete može se ostvariti mehanizmima projekcije i identifikacije (14). I treće, psihička trauma očeva može indirektno utjecati na dijete uzrokujući poremećaje u obiteljskom funkcioniranju (5).
Epidemiološka i klinička istraživanja su pokazala da djeca veterana oboljelih od PTSP-a imaju oko dva puta veći rizik za razvoj psihopatoloških simptoma od djece veterana bez PTSP-a te da se klinički značajni psihički problemi javljaju u oko $30 \%$ djece veterana oboljelih od PTSP-a (6).

Kvaliteta života je definirana kao tjelesna, psihička i socijalna dobrobit (15). Nezadovoljstvo kvalitetom života pokazuju i mlade osobe pogođene ratom. Raboteg-Šarić je našla da su mladi koji žive u područjima pogođenim ratom suočeni s brojnim poteškoćama vezanim uz nepovoljnu gospodarsku situaciju, ali i s poremećenim odnosima unutar obitelji, te se smatraju izgubljenom generacijom koja mora negdje drugdje potražiti bolju budućnost (2).

Cilj istraživanja je ispitati pojavnost psihičkih simptoma i kvalitetu života studenata u obitelji s iskustvom rata.

\section{ISPITANICI I METODE}

Istraživanje je provedeno primjenom presječne studije, slučajnim odabirom među studentskom populacijom oba spola. U istraživanje su bili uključeni studenti sa Sveučilišta u Mostaru od prve od pete godine. Pojedinačni podatci su bili i ostat će zaštićeni, te nedostupni javnosti, a dostupni su jedino konačni, skupni rezultati istraživanja. Istraživanje je sačinjavala ispitna i kontrolna skupina. Ispitnu skupinu činili su studenti iz obitelji s iskustvom rata $(\mathrm{n}=100)$, a kontrolnu skupinu činili su studenti čija obitelj nije sudjelovala u ratu $(\mathrm{n}=60)$.

Nakon provedenog istraživanja slijedila je kvantitativna analiza s korištenjem objektivnih rezultata koji su prikupljeni standardiziranim mjernim instrumentom. U istraživanju su korišteni sljedeći upitnici:

1. Sociodemografski upitnik osobne izrade, namjenski sačinjen za ovo istraživanje (sačinjavao je opća pitanja: dob, spol, godinu i naziv studija, akademski uspjeh, zadovoljstvo uspjehom, matrijalne mogućnosti, mjesto stanovanja, iskustvo rata članova obitelji).

2. Upitnik kvalitete života Svjetske zdravstvene organizacije WHOQOL-BREF je kraći oblik upitnika WHOQOL-100. Upitnik u cijelosti sadrži 
26 čestica. Kao rezultat upitnika WHOQOLBREF dobiva se profil kvalitete života koji polazi od modela koji objašnjava kvalitetu života kroz 4 područja: tjelesno zdravlje, psihičko zdravlje, socijalni odnosi i okolina (16).

3. Upitnik za samoprocjenu SCL-90 (Symptom Check List 90) kojim se procjenjuje tj. mjeri devet dimenzija ličnosti: somatizacija, opsesivno-kompulzivne reakcije, interpersonalna senzitivnost, depresivnost, anksioznost, fobična anksioznost, neprijateljstvo, paranoidne ideacije, psihoticizam (17).

Za statističku analizu rabljen je programski sustav SPSS for Windows (inačica 17.0., SPSS Inc, Chicago, Illinois, SAD) i Microsoft Excel (inačica 11.0., Microsoft Corporation, Redmond, WA, SAD). Rezultati za kategorijske varijable su izraženi kao frekvencija i postotaka, za parametrijske varijable kao aritmetička sredina i standardna devijacija. Za testiranje razlike među kategorijskim varijablama korišten je hi kvadrat test, a među parametrijskim varijablama Student t-test za nezavisne uzorke i jednosmjerna analiza varijance. Za testiranje povezanosti među varijablama korišten je Pearsonov test korelacije. Razina značajnosti od $\mathrm{p}<0,05$ je uzeta kao statistički značajna.

\section{REZULTATI}

Svi psihički simptomi statistički značajnije su izraženi kod studenata iz obitelji s iskustvom ratu u odnosu na studente koji nisu član obitelji s iskustvom rata, osim opsesivno kompulzivnih simptoma. Psihotična obilježja statistički značajnije su izražena kod studenata iz obitelji s iskustvom rata u odnosu na studente koji nisu članovi obitelji s iskustvom rata $(\mathrm{p}=0,013)$. Nespecifični simptomi statistički značajnije su izraženi kod studenata iz obitelji s iskustvom rata u odnosu na studente koji nisu članovi obitelji s iskustvom rata $(\mathrm{p}=0,04)$ (Tablica 1.).
Tablica 1. Psihički simptomi mjereni SCL- 90 upitnikom u ispitivanoj $i$ kontrolnoj skupini.

\begin{tabular}{lcccccc}
\hline & \multicolumn{7}{c}{$\begin{array}{c}\text { Raspodjela simptoma prema } \\
\text { skupinama }\end{array}$} \\
\cline { 2 - 7 } & $\begin{array}{c}\text { Ispitivana } \\
\text { skupina }\end{array}$ & $\begin{array}{c}\text { Kontrolna } \\
\text { skupina }\end{array}$ & $t$ & $\mathrm{t}$ \\
\cline { 2 - 7 } & $\bar{X}$ & SD & $\bar{X}$ & SD & & \\
\hline Somatizacija & 0,87 & 0,52 & 0,71 & 0,48 & 1,910 & 0,058 \\
\hline $\begin{array}{l}\text { Opsesivno kompulzivni } \\
\text { simptomi }\end{array}$ & 0,43 & 0,41 & 0,43 & 0,39 & 0,099 & 0,921 \\
\hline $\begin{array}{l}\text { Inetrpersonalna } \\
\text { vulnerabilnost }\end{array}$ & 0,63 & 0,55 & 0,53 & 0,50 & 1,171 & 0,244 \\
\hline Depresija & 0,59 & 0,46 & 0,54 & 0,52 & 0,727 & 0,468 \\
\hline Anksioznost & 0,46 & 0,46 & 0,36 & 0,44 & 1,256 & 0,211 \\
\hline Agresivnost & 0,63 & 0,54 & 0,59 & 0,63 & 0,440 & 0,660 \\
\hline Fobije & 0,58 & 0,56 & 0,47 & 0,50 & 1,268 & 0,207 \\
\hline Paranoja & 0,44 & 0,48 & 0,34 & 0,44 & 1,276 & 0,204 \\
\hline Psihotična obilježja & 0,47 & 0,43 & 0,30 & 0,39 & 2,513 & 0,013 \\
\hline Nespecifični simptomi & 0,45 & 0,45 & 0,31 & 0,39 & 2,053 & 0,042 \\
\hline
\end{tabular}

Simptomi somatizacije su statistički značajnije izraženi $(p=0,007)$ kod studenata čija je majka bila sudionik rata u odnosu na studente iz obitelji gdje su oba roditelja bili sudionici rata. Simptomi anksioznosti statistički značajnije su izraženi $(\mathrm{p}=0,020)$ kod onih studenata čija je majka bila sudionik rata u odnosu na studente iz obitelji gdje su oba roditelja bili sudionici rata. Također i simptomi paranoje statistički značajno su više izraženi $(p=0,007)$ kod studenata čija je majka bila sudionk rata u odnosu na studente iz obitelji gdje su oba roditelja bili sudionici rata (Tablica 2).

Tablica 2. Psihički simptomi mjereni SCL-90 upitnikom sobzirom na člana obitelji koji je imao iskustvo rata

\begin{tabular}{|c|c|c|c|c|c|c|c|c|}
\hline & \multicolumn{6}{|c|}{ član obitelji s iskustvom rata } & \multirow{3}{*}{$\mathrm{F}$} & \multirow{3}{*}{$\mathrm{p}$} \\
\hline & \multicolumn{2}{|c|}{ Otac } & \multicolumn{2}{|c|}{ Majka } & \multicolumn{2}{|c|}{ Oba roditelja } & & \\
\hline & $\bar{x}$ & SD & $\bar{x}$ & SD & $\bar{X}$ & SD & & \\
\hline Somatizacija & 0,90 & 0,48 & 10,43 & 0,47 & 0,74 & 0,52 & 5,291 & 0,007 \\
\hline $\begin{array}{l}\text { Opsesivno } \\
\text { kompulzivni simptomi }\end{array}$ & 0,47 & 0,46 & 0,62 & 0,37 & 0,34 & 0,34 & 1,798 & 0,171 \\
\hline $\begin{array}{l}\text { Inetrpersonalna } \\
\text { vulnerabilnost }\end{array}$ & 0,69 & 0,61 & 0,89 & 0,49 & 0,51 & 0,44 & 2,025 & 0,137 \\
\hline Depresija & 0,66 & 0,49 & 0,90 & 0,57 & 0,45 & 0,37 & 3,949 & 0,052 \\
\hline Anksioznost & 0,47 & 0,49 & 0,93 & 0,48 & 0,37 & 0,38 & 4,092 & 0,020 \\
\hline Agresivnost & 0,68 & 0,58 & 0,83 & 0,45 & 0,53 & 0,49 & 1,338 & 0,267 \\
\hline Fobije & 0,57 & 0,56 & 0,81 & 0,78 & 0,56 & 0,52 & 0,536 & 0,587 \\
\hline Paranoja & 0,49 & 0,52 & 0,83 & 0,46 & 0,30 & 0,37 & 4,275 & 0,017 \\
\hline Psihotična obilježja & 0,50 & 0,45 & 0,75 & 0,36 & 0,38 & 0,41 & 2,306 & 0,105 \\
\hline Nespecifični simptomi & 0,48 & 0,46 & 0,74 & 0,40 & 0,37 & 0,44 & 1,970 & 0,145 \\
\hline
\end{tabular}


Simptomi paranoje statistički značajnije su izraženi $(p=0,024)$ kod studenata čiji je član obitelji nastradao za vrijeme rata u odnosu na studente čiji član obitelji nije nastradao za vrijeme rata. Nespecifični simptomi statistički značajnije $(\mathrm{p}=0,028)$ su izraženi kod studenata čiji je član obitelji nastradao za vrijeme rata u odnosu na studente čiji član obitelji nije nastradao za vrijeme rata (Tablica 3).

Tablica 3. Psihički simptomi mjereni SCL-90 upitnikom s obzirom na stradanje člana obitelji

\begin{tabular}{lcccccc}
\hline & \multicolumn{6}{c}{ Stradanje članova obitelji } \\
\cline { 2 - 7 } & \multicolumn{7}{c}{ Da } & Ne & t & p \\
\cline { 2 - 7 } & $\bar{X}$ & SD & $\bar{X}$ & SD & & \\
\hline Somatizacija & 0,86 & 0,56 & 0,87 & 0,50 & 0,103 & 0,918 \\
\hline Opsesivno kompulzivni simptomi & 0,54 & 0,55 & 0,38 & 0,33 & 1,499 & 0,142 \\
\hline Inetrpersonalna vulnerabilnost & 0,77 & 0,64 & 0,57 & 0,49 & 1,754 & 0,083 \\
\hline Depresija & 0,68 & 0,51 & 0,56 & 0,44 & 1,248 & 0,215 \\
\hline Anksioznost & 0,56 & 0,53 & 0,41 & 0,43 & 1,347 & 0,184 \\
\hline Agresivnost & 0,71 & 0,62 & 0,60 & 0,51 &, 986 & 0,327 \\
\hline Fobije & 0,76 & 0,63 & 0,50 & 0,50 & 1,957 & 0,056 \\
\hline Paranoja & 0,63 & 0,60 & 0,35 & 0,39 & 2,334 & 0,024 \\
\hline Psihotična obilježja & 0,59 & 0,54 & 0,42 & 0,37 & 1,835 & 0,070 \\
\hline Nespecifični simptomi & 0,62 & 0,54 & 0,37 & 0,39 & 2,272 & 0,028 \\
\hline
\end{tabular}

Ne postoji statistički značajnija razlika niti u jednom području kvalitete života između studenata iz obitelji s iskustvom rata i studenta koji nisu član obitelji s iskustvom rata (Tablica 4).

Tablica 4. Profili kvalitete života mjereni WHOQOLBREF upitnikom u ispitivanoj i kontrolnoj skupini.

\begin{tabular}{lcccccc} 
WHOQ0L-BREF & \multicolumn{7}{l}{ Raspodjela profila prema skupinama } \\
\cline { 2 - 7 } & \multicolumn{7}{l}{ Ispitivana skupina } & \multicolumn{7}{l}{ Kontrolna skupina } & $\mathrm{t}$ & $\mathrm{p}$ \\
\cline { 2 - 7 } & $\bar{X}$ & SD & $\bar{X}$ & SD & & \\
\hline Tjelesno zdravlje & 16,22 & 2,25 & 16,19 & 2,06 & 0,081 & 0,935 \\
\hline Psihičko zdravlje & 15,43 & 2,45 & 15,65 & 2,34 & 0,558 & 0,578 \\
\hline Socijalni odnosi & 14,99 & 3,06 & 14,82 & 2,49 & 0,345 & 0,731 \\
\hline Okolina & 14,32 & 2,51 & 14,22 & 2,53 & 0,229 & 0,819 \\
\hline Ukupno & 15,52 & 2,31 & 16,07 & 2,07 & 1,500 & 0,136 \\
\hline
\end{tabular}

Domena okoline kvalitete života, odnosno briga o okolini, je statistički značajno lošija $(\mathrm{p}=0,028)$ kod studenata čiji je otac bio sudionik rata u odnosu na studente čija je majka bila sudionik rata (Tablica 5). Ne postoji statistički značajnija razlika za ostale domene kvalitete života između studenata iz obitelji $s$ iskustvom rata i studenta koji nisu član obitelji s iskustvom rata.

Tablica 5. Profili kvalitete života mjereni WHOQOLBREF upitnikom s obzirom na člana obitelji koji je imao iskustvo rata

Član obitelji s iskustvom rata

\begin{tabular}{lcccccccc}
\hline WHOQOL-BREF & \multicolumn{2}{c}{ Otac } & \multicolumn{2}{c}{ Majka } & Oba roditelja & $F$ & $p$ \\
\hline & $\bar{X}$ & SD & $\bar{X}$ & SD & $\bar{X}$ & SD & & \\
\hline Tjelesno zdravlje & 16,23 & 2,29 & 14,48 & 3,08 & 16,48 & 1,97 & 2,110 & 0,127 \\
\hline Psihičko zdravlje & 15,35 & 2,75 & 14,22 & 2,59 & 15,74 & 1,91 & 1,058 & 0,351 \\
\hline Socijalni odnosi & 14,98 & 3,24 & 12,22 & 2,72 & 15,44 & 2,64 & 2,985 & 0,055 \\
\hline Okolina & 14,62 & 2,53 & 11,75 & 3,42 & 14,28 & 2,15 & 3,726 & 0,028 \\
\hline Ukupno & 15,21 & 2,49 & 14,67 & 3,01 & 16,11 & 1,80 & 2,167 & 0,120 \\
\hline
\end{tabular}

Statistički značajno lošiji akademski uspjeh pokazuju studenti čiji su članovi obitelji direktno sudjelovali u ratu u odnosu na studente čiji članovi obitelji nisu direktno sudjelovali u ratu (Slika 1).

\section{RASPRAVA}

Epidemiološka i klinička istraživanja su pokazala da djeca veterana oboljelih od PTSP-a imaju oko dva puta veći rizik za razvoj psihopatoloških simptoma od djece veterana bez PTSP-a te da se klinički značajni psihički problemi javljaju u oko $30 \%$ djece veterana oboljelih od PTSP-a (6). Harkness je našla da djeca veterana od 6 do 16 godina starosti često manifestiraju depresiju, anksioznost, hiperaktivnost, delinkventno ponašanje, slabu socijalizaciju i probleme $u$ školi te da nasilje $u$ obiteljima veterana s PTSP-om više doprinosi problemima djece nego sam PTSP (18). Kliničko istraživanje u Hrvatskoj pokazalo je da djeca očeva veterana s PTSP-om u dobi od 12 do 18 godina imaju, također, gotovo dva puta veći rizik za ozbiljne psihičke probleme od adolescenata čiji očevi veterani nemaju PTSP (19). Rezultati našeg istraživanja pokazali su da kod studenata koji su član obitelji s iskustvom rata nalazimo više psihotičnih obilježja i nespecifičnih simptoma nego kod studenata čiji članovi nemaju ratnog iskustva.

Djeca veterana s PTSP-om u Bosni i Hercegovini imala su više depresivnih i somatizacijskih 


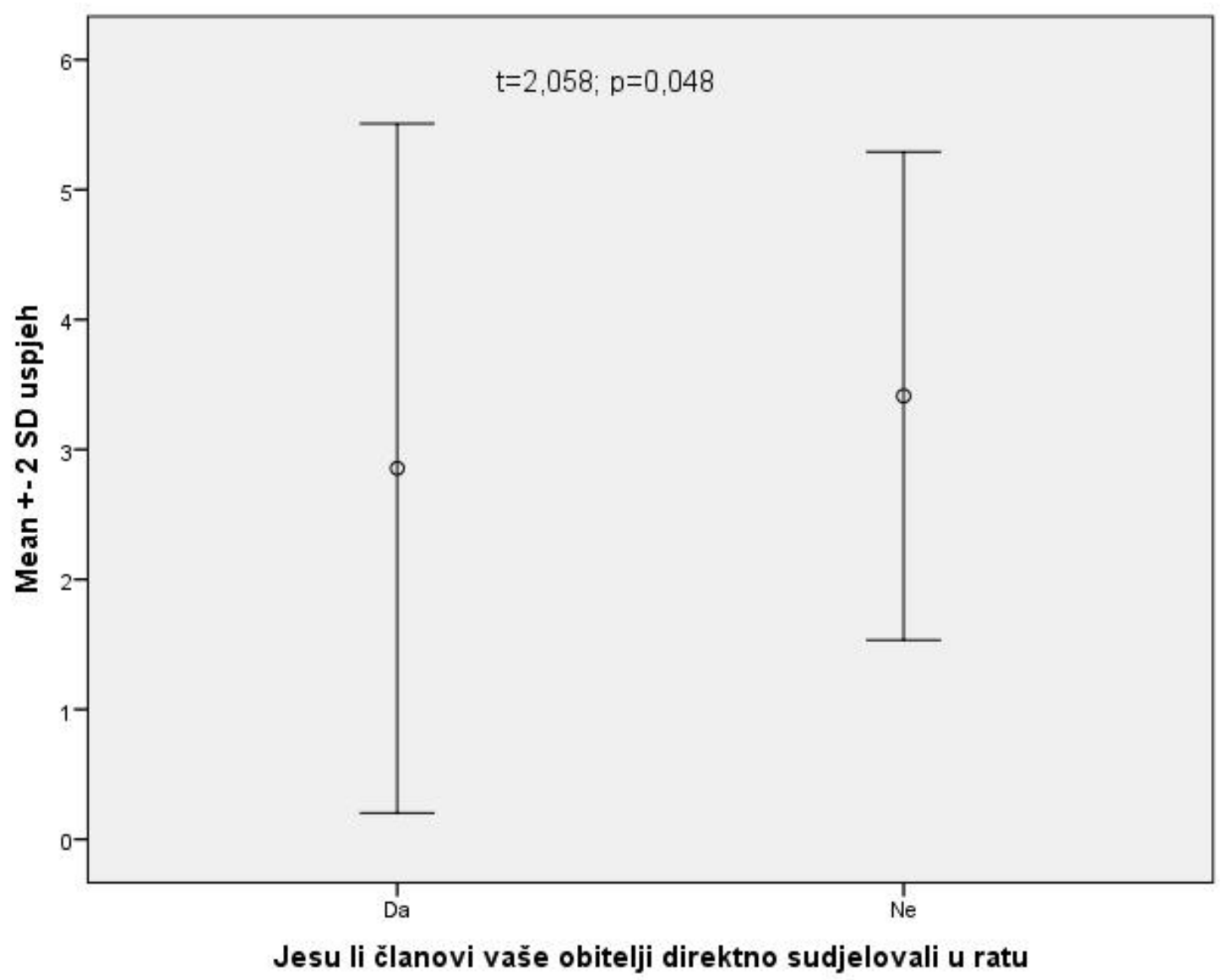

Slika 1. Uspjeh ispitanika prema direktnom sudjelovanju članova obitelji u ratu

simptoma, kao što su bolovi u trbuhu, problemi s hranjenjem i disanjem, te su bila više zabrinuta i uznemirena od djece veterana bez PTSP-a (20). Ahmadzadeh i Malekian su pronašli značajno povišenu razinu agresije i anksioznosti u adolescenata čiji su očevi bili veterani rata u Iranu s kroničnim PTSP-om u usporedbi s djecom čiji očevi nisu bili veterani (21). Istraživanja su potvrdila da se PTSP-om roditelja može objasniti trećina varijance maladaptivnih psihosocijalnih poteškoća djece kao i da PTSP roditelja pouzdano predviđa navedene manifestacije. Djeca veterana Vijetnamskog rata $s$ PTSP-om imala su klinički značajne psihičke probleme više od dva puta češće od djece veterana bez PTSP-a (3). Veterani vijetnamskog rata s PTSP-om su kod svojih sinova školske dobi opažali više hiperaktivnosti, agresivnog i delinkventnog ponašanja, a kod kćeri adolescentne dobi od 16 do 22 godine starosti više depresije i socijalne izolacije u odnosu na djecu iste dobi i spola čiji očevi veterani nisu imali
PTSP. U istom je istraživanju uočeno da djeca vijetnamskih veterana s PTSP-om imaju više problema u uspostavljanju i održavanju prijateljskih odnosa s vršnjacima u usporedbi s djecom veterana bez PTSP-a (22).

Naši rezultati pokazuju da su simptomi paranoje te nespecifični simptomi više izraženi kod onih studenata čiji je član obitelji nastradao za vrijeme rata. Simptome somatizacije te simptome paranoje i anksioznosti nalazimo više kod onih studenata kod kojih je majka imala iskustvo rata u odnosu na one studente kod kojih su oba roditelja imala iskustvo rata. Harkness je utvrdio da djeca ratnih veterana često manifestiraju poteškoće u akademskoj karijeri, dijadnim vezama i emocionalnoj regulaciji (23). Kod djece veterana s PTSP-om adolescentne i odrasle dobi od 14 do 35 godina starosti, Beckham i sur. su pronašli više uporabe ilegalnih droga, problema u ponašanju, simptoma PTSP-a i hostilnosti (24). Najveće razlike između opće populacije 
i traumatiziranih osoba dobivaju se u podrućju zdravstvenog aspekta kvalitete života. Izloženost traumatskim iskustvima, po definiciji, dovodi do izrazito neugodnih doživljaja i uznemirujućih reakcija, koje, ako traju dulje vrijeme, mogu narušiti mentalno zdravlje, a time potencijalno kvalitetu života pojedinca. Priebe i suradnici su pokazali da osobe koje su tražile psihijatrijsku pomoć, a imaju više posttraumatskih, depresivnih i anksioznih smetnji imaju imati lošiju kvalitetu života (25). Naše istraživanje je pokazalo da nema statistički značajne razlike u kvaliteti života između studenata iz obitelji $\mathrm{s}$ iskustvom rata i studenata koji nisu član obitelji s iskustvom rata.

\section{ZAKLJUČAK}

Postoji statistički značajna razlika u pojavnosti psihičkih simptoma između studenata iz obitelji s iskustvom rata i studenata koji nisu član obitelji s iskustvom rata. Svi psihički simptomi statistički su više izraženi kod studenata iz obitelji s iskustvom rata u odnosu na studente koji nisu član obitelji s iskustvom rata, osim opsesivno kompulzivnih simptoma. Nije nađeno statistički značajne razlike u kvaliteti života između ispitivane i kontrolne skupine. Domena okoline kvalitete života, odnosno briga o okolini, je statistički značajno lošija kod studenata čiji je otac bio sudionik rata u odnosu na studente čija je majka bila sudionik rata. Ne postoji statistički značajnija razlika za ostale domene kvalitete života između studenata iz obitelji s iskustvom rata i studenta koji nisu član obitelji s iskustvom rata.

\section{LITERATURA}

1. Yehuda R, Davidson J. Cilinician's Manual on Posttraumatic Stress Disorder. Science Press Ltd, London, UK. 2000;1-11.

2. Jordan BK. Problems in families of male Vietnam veterans with posttraumatic stress disorder. J Consult Clin Psychol. 1992;60:916-926.

3. Jezik traume i sekundarna traumatizacija (Internet) Pristupljeno 20.12.2015. Dostupno na: http://scindeks-clanci.ceon.rs/data/pdf/03502538/2003/0350-25380302079G.pdf.
4. Davidson AC, Mellor DJ. The adjustment of children of Australian Vietnam veterans: is there evidence for the transgenerational transmission of war-related trauma. Aust N Z J Psychiatry. 2001;35:345-51.

5. Figley CR. Treating stress in families. New York. 1989.

6. Galovski T, Lyons JA. Psychological sequelae of combat violence: a review of the impact of PTSD on the veteran's family and possible interventions. Aggress Viol Behav. 2004;9:477-501.

7. Kaufman J. Brain derived neurotrophic factors-5-HTTLPR gene interactions and environmental modifiers of depression in children. Biol Psychiatry. 2006;59:673-80.

8. Roy A. Interaction of FKBP5, a stress-related gene, with childhood trauma increases the risk for attempting suicide. Neuropsychopharmacology. 2010;35:1674-83.

9. Yehuda R, Bell A, Bierer LM, Schmeidler J. Maternal, notpaternal, PTSD is related to increased risk for PTSD in offspring of Holocaust survivors. J Psychiatr Res. 2008;42:1104-11.

10. Yehuda R. Transgenerational effects of posttraumatic stress disorder in babies of mothers exposed to the World Trade Center attacks during pregnancy. J Clin Endocrinol Metab. 2005;90:411518.

11. Oztop E. Mirror neurons: functions, mechanisms and models. Neurosci Lett. 2013;540:43-55.

12. Rosenheck R, Fontana A. Transgenerational effects of abusive violence on the children of Vietnam combat veterans. J Trauma Stress. 1998;11:73141.

13. Harkness LL. Transgenerational transmission of war-related trauma. U: Wilson JP, Raphael B, ur. International handbook of traumatic stress syndromes. New York: Plenum. 1993.

14. Srour RW, Srour A. Communal and familial war-related stress factors: The case of the Palestinian child. J Loss Trauma. 2005;11:289-09.

15. Kvaliteta života kod branitelja s posttraumatskim stresnim poremećajem i komorbidnim psihičkim i tjelesnim bolestima (Internet) Pristuplje- 
no 29.12.2015. Dostupno na:. https://zir.nsk.hr/ islandora/object/hrstud\%3A12.

16. Skevington SM, Lotfly MI, O'Connell KA. The World Health Organization's WHOQOL-BREF quality of life assessment: Psychometric properties and results of the international field, a report from the WHOQOL 26. Group. Quality of Life Research 13. 2004;299-310.

17. Derogatis LR, Savitz KL. The SCL-90-R and the Brief Symptom Inventory (BSI) in Primary Care In. ME. Maruish, ur. Handbook of psychological assessment in primary care settings, Volume 236 Mahwah, NJ: Lawrence Erlbaum Associates. 2000;297-334.

18. Harkness LL. The effect of combat-related PTSD on children. National Center for PTSD Clinical Newsletter 1991;2:12-13.

19. Harkness L, Zador N. Treatment of PTSD in families and couples. In: Wilson JP, Friedman MJ, Lindy JD ur. Treating psychological trauma and PTSD. New York: Guilford. 200;.335-53.
20.Zalihic A, Zalihic D, Pivic G. Influence of posttraumatic stress disorder of the fathers on other family members. Bosn J Basic Med Sci. 2008;8:20-6.

21. Breslau N. Sex differences in posttraumatic stress disorder. Arch Gen Psychiatry. 1997;54:10441048.

22. Parsons J, Kehle TJ, Owen SV. Incidence of behavior problems among children of Vietnam veterans. School Psychol Int. 1990;11:253-9.

23. Harkness LL. The effect of combat-related PTSD on children. National Center for PTSD Clinical Newsletter. 1991;2:12-13.

24. Beckham JC. Minnesota Multiphasic Personality Inventory profiles of Vietnam combat veterans with posttraumatic stress disorder and their children. J Clin Psychol. 1997;53:847-52.

25. Kvaliteta života osoba pogođenih ratom (Internet) Pristupljeno 29.12.2015. Dostupno na: http://hrcak.srce.hr/index.php?show=clanak\&id_clanak_jezik=29432. 


\title{
MENTAL SYMPTOMS AND QUALITY OF LIFE OF STUDENTS FROM FAMILIES WITH EXPERIENCE OF WAR
}

\author{
Irena Babic, Dragan Babic, Marko Martinac, Ivan Vasilj, Marina Vasilj
}

Faculty of Health Studies, University of Mostar, Bijeli Brijeg bb, 88300 Mostar, Bosnia and Herzegovina

\begin{abstract}
INTRODUCTION: Previous studies consistently show a connection between war PTSD veterans and psychopathological symptoms in their family. The negative impact of psychological trauma on the people close to the individual suffering from PTSD is conceptualized through the notion of secondary traumatization. The aim of this paper is to examine the psychological symptoms and quality of life of students from families with the experience of war.

SUBJECTS AND METHODS: The study included students from the University of Mostar from the first to the fifth year $(n=160)$. The study was conducted by using cross-sectional study, randomly among students of both sexes. Socio-demographic questionnaire, questionnaire quality of life of the World Health Organization WHOQOL-BREF and Self-Assessment Questionnaire SCL- 90th were used for the research.

RESULTS: All mental symptoms were statistically significantly expressed in students from families with experience of war in relation to students who are not members of families with experience of the war, except for obsessive compulsive symptoms. Psychotic features are significantly expressed in students from families with experience of war in relation to students who are not family members who experienced the war as well as non-specific symptoms. Symptoms of somatization, anxiety and paranoia were significantly more pronounced among students whose mother was a participant of the war compared to students from families where both parents were participants in the war. Symptoms of paranoia and non-specific symptoms are significantly more pronounced among students whose family member died during the war compared to students whose family member was not killed during the war. There was no statistically significant difference in any area of quality of life among students from families with experience of war and students who are not members of families with war experience.
\end{abstract}

CONCLUSION: Students from families with experience of the war had a significantly higher incidence of psychiatric symptoms. Between the two groups there was no statistically significant difference in relation to the quality of life.

Keywords: psychological symptoms, quality of life, students, war.

Correspondence:

Babic Irena, master of nursing

e-mail: babicirena28@gmail.com 